\title{
Observations on bee species visiting white clover in New Zealand pastures
}

\author{
Louise Malone $^{1 *}$, James Aulsford ${ }^{1}$, Brad Howlett ${ }^{2}$, Cynthia Scott-Dupree $^{3}$, Nicolas Bardol ${ }^{4}$ and Barry Donovan ${ }^{5}$ \\ ${ }^{1}$ The New Zealand Institute for Plant and Food Research Ltd, Private Bag 92 169, Auckland 1142, New Zealand. \\ ${ }^{2}$ The New Zealand Institute for Plant and Food Research Ltd, Canterbury Agriculture and Science Centre, Private Bag 4704, \\ Christchurch 8140, New Zealand. \\ ${ }^{3}$ Department of Environmental Biology, University of Guelph, Guelph, Ontario, N1G 2W1, Canada. \\ ${ }^{4}$ Agrocampus Rennes, Rennes, France. \\ ${ }^{5}$ Donovan Scientific Insect Research, Canterbury Agriculture and Science Centre, Private Bag 4704, Christchurch 8140, \\ New Zealand.
}

Received 6 January 2009, accepted subject to revision 26 January 2010, accepted for publication 24 May 2010.

*Corresponding author: Email: louise.malone@plantandfood.co.nz

Keywords: Apoidea, Lasioglossum spp., Leioproctus spp., Bombus terrestris, Apis mellifera

There is currently worldwide concern about a loss of pollinating insects, with wild species being adversely affected by habitat destruction and managed honey bees decreasing in number because of the global spread of bee pests and diseases such as the varroa mite (Varroa destructor Anderson \& Trueman). There have been no recent studies to determine whether New Zealand, like other countries, is suffering from a decline in pollinators.

White clover, Trifolium repens $\mathrm{L}$., is the most abundant insectpollinated flowering agricultural plant in New Zealand, with the greatest economic value. The last major studies on clover pollination in New Zealand pastures were published over 20 years ago and focussed on South Island pastures with emphasis on honey bee and bumble bee pollination (Palmer-Jones et al., 1962; Forster, 1974; Pearson, 1985). With the recent spread of varroa throughout the North Island and its discovery in the South Island in 2006, the mechanisms and efficiency of white clover pollination in pastures may be in the process of significant change. Recent unpublished studies in the South Island identified only honey bees, bumble bees and native bees as important pollinators of white clover grown for seed (Howlett, pers. comm.). Lasioglossum spp., Leioproctus vestitus (Howlett, pers. comm.) and Leioproctus pango (Donovan, pers. comm.) are currently the only documented native bee species readily visiting white clover florets, with $L$. vestitus likely to be an efficient pollinator (Walker, pers. comm.). L. vestitus occurs throughout New Zealand (Donovan, 2007), but the few documented observations of it visiting white clover have been in South Island pastures (Palmer-Jones et al., 1962; Quinn, 1984).

Here we present observations on the occurrence of bee species visiting flowering white clover at a North Island site over two successive summers. The study site was a mixed-sward pasture used for cattle grazing and hay production located near Clevedon, south of Auckland (Lat. $37^{\circ} 2^{\prime} \mathrm{S}$, Long. $175^{\circ} 0^{\prime} \mathrm{E}$ ). Flowering trees nearby included ti kouka (Cordyline australis), weeping willow (Salix babylonica), privet (Ligustrum chinensis), pussy willow (Salix caprea), and poroporo (Solanum laciniatum). In the study area, the following were flowering during the observation periods: white clover ( $T$. repens), red clover (Trifolium pratense), buttercup (Ranunculus repens), Mexican daisy (Erigeron karvinskianus), hawkbit (Leontodon taraxacoides), lotus (Lotus pedunculatus), and narrow-leaved plantain (Plantago lanceolata). There were no permanent registered honey bee apiaries within $2 \mathrm{~km}$ of the site and observations were not made until pollinator honey bee hives had been removed from a neighbouring kiwifruit orchard.

Bees were collected and observed over three periods: 8 to 29 December 2006, 9 February to 9 March 2007, and 10 December 2007 to 27 January 2008. Livestock were excluded from the study area (40 $x 20 \mathrm{~m}$ ) within the paddock. Five pan traps (white plastic pans $8 \times 39$ x $27 \mathrm{~cm}$ placed on bricks and filled with about $2 \mathrm{~L}$ of $1 \%$ honey solution) and five double-sided white sticky traps (18 x $19 \mathrm{~cm}$, mounted $110 \mathrm{~cm}$ above the ground on wooden stakes) were placed throughout the enclosure. Pan traps were emptied and re-filled three times each week and sticky traps replaced weekly. Hymenopteran specimens about $5 \mathrm{~mm}$ in length or longer were removed from pan traps, stored in ethanol (70\% aqueous) and later mounted, dried and identified. Sticky traps were wrapped in plastic film and stored frozen for later removal, mounting and identification of Hymenoptera $\geq 5 \mathrm{~mm}$ 
Table 1. Numbers of adult bees caught in two types of trap at a South Auckland clover pasture site over two summers. $* 10$ collections, $* * 8$ collections, $* * * 9$ collections, $* * * * 12$ collections.

\begin{tabular}{|c|c|c|c|c|c|c|c|}
\hline Species & $\begin{array}{l}\text { December } \\
\text { 2006* }\end{array}$ & $\begin{array}{c}\text { February/ } \\
\text { March } \\
2007^{* *}\end{array}$ & $\begin{array}{c}\text { December } \\
2007 * * *\end{array}$ & $\begin{array}{c}\text { January } \\
2008 * * * *\end{array}$ & $\begin{array}{l}\text { Pan } \\
\text { traps }\end{array}$ & $\begin{array}{l}\text { Sticky } \\
\text { traps }\end{array}$ & Totals \\
\hline Apis mellifera & 171 & 196 & 75 & 188 & 571 & 59 & 630 \\
\hline Bombus terrestris & 6 & 14 & 2 & 2 & 24 & 0 & 24 \\
\hline Lasioglossum cognatum & 272 (all + ) & $45(42+, 3 \hat{\circ})$ & 18 (all + ) & 6 (all + ) & 321 & 20 & $341(338+, 3 \hat{\circ})$ \\
\hline Lasioglossum sordidum & 7 (all + ) & $14\left(9+, 5{ }^{\lambda}\right)$ & $8(5 \circ, 3 \hat{\circ})$ & $52\left(21+, 31{ }^{\Uparrow}\right)$ & 66 & 15 & $81\left(42+, 39{ }^{\Uparrow}\right)$ \\
\hline Leioproctus boltoni & $1(q)$ & 0 & 0 & 0 & 1 & 0 & $1(+)$ \\
\hline Leioproctus imitatus & $94(50+, 44 \bigcirc)$ & 0 & $11(6+5 \hat{)})$ & 2 (both + ) & 56 & 51 & $107\left(58+49{ }^{\lambda}\right)$ \\
\hline Leioproctus metallicus & 0 & 0 & 0 & 1 ( $(+)$ & 0 & 1 & $1(q)$ \\
\hline Leioproctus paahaumaa & 2 (both $\overbrace{}^{\lambda}$ ) & $1(\overbrace{}^{\lambda})$ & 0 & $98(81+, 17 \precsim)$ & 98 & 3 & $101(81$ ㅇ, 20ㄱ) \\
\hline Leioproctus pango & $6(4+, 2 \hat{\circ})$ & 0 & 0 & 0 & 5 & 1 & $6\left(4+2{ }^{\lambda}\right)$ \\
\hline
\end{tabular}

long. Species identifications were made by J. Aulsford and L. Malone for honey bees and bumble bees and other species by B. Donovan (Donovan, 2007).

Nine species of Apoidea with bodies large enough to pollinate white clover were collected: Apis mellifera L., B. terrestris, and seven native species, Lasioglossum cognatum (Smith), Lasioglossum sordidum (Smith), Leioproctus boltoni (Cockerell), Leioproctus imitatus Smith, Leioproctus metallicus (Smith), Leioproctus paahaumaa Donovan and Leioproctus pango Donovan (Table 1). Some of the native bees were observed visiting clover flowers, but only one of these specimens (a female $L$. sordidum) was captured and identified. Lasioglossum cognatum, L. sordidum and $L$. pango have previously been observed foraging on white clover (Donovan, 2007). Leioproctus imitatus was a commonly-trapped species near Auckland, but it has not been recorded as a pollinator of white clover. There is also no record of $L$. paahaumaa foraging on white clover; it is possible the Auckland-trapped specimens had been attracted to the pasture by flowers of the lesser hawkbit, since other records suggest a preference for Asteraceae (Donovan, 2007). Neither L. boltoni nor $L$. metallicus has been observed foraging on T. repens (Donovan, 2007) and these two species were rare at the Auckland site.

The abundance of native bees was not consistent over the study period, suggesting their emergence and/or their preference for foraging in such pastures might be confined to relatively brief periods of time, compared to honey bees. Certainly most New Zealand native bee species seem to have evolved so that their flight periods coincide with the flowering of nectar- and pollen-bearing native plants (Donovan, 2007). The timing of some of our observations suggests support for there being species- and sometimes sex-specific flight periods for some New Zealand native bee species (Donovan, 2007).
Different weather conditions from one season to the next may have also affected the abundance of some species trapped at Auckland, either directly or via effects on the availability of forage both inside and adjacent to the study plots. For example, higher numbers of $L$. cognatum and L. imitatus during December 2006 compared with December 2007 may have been related to cooler December temperatures in 2006 compared with 2007 (weather records from Pukekohe Research Station).

In summary, the results suggest some native bee species could supplement $A$. mellifera as white clover pollinators in New Zealand, especially if different native species are able to forage on the flowers in succession over the summer.

\section{Acknowledgements}

We acknowledge financial support from the C. Alma Baker Trust for the studies during the summer of $2007 / 2008$, and the New Zealand Royal Society's International Science and Technology Linkages Fund for supporting Professor Scott-Dupree's visit during December 2006. We thank Mr Alan Jack, Clevedon, Auckland, for allowing us access to his property. Weather records were kindly supplied by Mr Warwick Henshall of the New Zealand Institute for Plant and Food Research Ltd. Practical assistance from Preben Kristiansen (Swedish Beekeepers Association, Mantorp, Sweden), Bruce Philip, Emma Barraclough, Jacqui Todd and Jo Poulton (all of the New Zealand Institute for Plant and Food Research Ltd) is gratefully acknowledged. 


\section{References}

DONOVAN, B (2007) Apoidea (Insecta: Hymenoptera). Fauna of New Zealand. Ko te Aitanga Pepeke o Aotearoa. Number 57. Manaaki Whenua Press; Lincoln, Canterbury, New Zealand. pp. 295

FORSTER, I W (1974) Behaviour and effectiveness of bees in pollinating legumes. Proceedings of the New Zealand Grassland Association 36: 105-110.

PALMER-JONES, T; FORSTER, I W; JEFFREY, G L (1962) Observations on the role of the honey bee and bumble bee as pollinators of white clover (Trifolium repens $\mathrm{L}$.) in the Timaru district and Mackenzie country. New Zealand Journal of Agricultural Research 5: 318-325.
PEARSON, W D (1985) White clover seed production in high country pasture. In Chapman, R B (Ed) Proceedings of the 4th Australasian Conference for Grassland Invertebrate Ecology, Canterbury, New Zealand, 13-17 May, 1985. Caxton Press; Christchurch, New Zealand. pp. 121-126.

QUINN, P (1984) Survey of native bees (Hymenoptera: Colletidae and Halictidae) in the Mackenzie Basin. New Zealand Entomologist 8: 41-44. 